\title{
Research on Entrepreneurship Education based on Entrepreneurial Ecosystem
}

\author{
Hongzhen $\operatorname{Lin}^{1}$, Sen Yang ${ }^{2}$ \\ 1School of Hengda Management, Wuhan University of Science and Technology Wuhan, China \\ Distinct addresses: 947 He Ping Street, Hubei Wuhan 430081, China \\ linhongzhen@126.com \\ 2School of Hengda Management, Wuhan University of Science and Technology Wuhan, China \\ Distinct addresses: 947 He Ping Street, Hubei Wuhan 430081, China \\ 8392806422@qq.com
}

\begin{abstract}
The purpose of this paper is to research entrepreneurship education based on Entrepreneurial ecosystem. Using the method of document study and Comparison method obtained necessary data in order to understand entrepreneurship education. Entrepreneurship education is a systematic project. The era of innovation and entrepreneurship calls for entrepreneurial education to adapt to the economic and social development and follow the law of education. How to promote the healthy and sustainable development of entrepreneurial education for people is a major problem in the theoretical research and practical exploration of entrepreneurship education. Under the background of highly concerned about entrepreneurship education in the government, society and universities, it is an important way to establish entrepreneurship education ecosystem, set up the correct values, realize the integration of entrepreneurial courses and professional courses, effectively integrate resources inside and outside school, and guide the connotation development of entrepreneurship education.
\end{abstract}

Keywords-Target; Curriculum system; Entrepreneurial ecosystem; Entrepreneurship education Introduction

\section{INTRODUCTION}

Some foreign universities break through the campus fence and single line teaching mode, give full play to the social network, the linkage of internal and external resources, curriculum integration, teachers, funds, policy and business intermediary organization, to achieve a virtuous cycle between scientific research and of the three industry and teaching through effective coordination mechanism, so as to construct the ecosystem of entrepreneurship education. Ecosystem concept is used to analyze the relationship between the natural environment in different physical and biological factors. In 1930s, some scholars at University of Chicago began to introduce the concept of ecology to sociological research to describe the structure of social community. In 1950s, in order to understand the relationship between community, city and environment in human society, human ecosystem became popular as a biological sociology method. The concept of "ecology" is not only used to explain natural succession, competition and metabolism in nature, but also widely used to explain various complex relations between society and human system. Entrepreneurship is a complex social phenomenon, which involves the dynamic relationship of nature, society and people. In the social community structure and operation system, elements such as policy, finance, education, culture, market, human capital, support system and other elements interact to form an entrepreneurial ecosystem for healthy development. When the entrepreneur has the necessary human resources, funds and expert resources, the environment is encouraged and protected by government policy, and it is the easiest to succeed. To this end, many international organizations have begun to pay attention to the entrepreneurial ecosystem and make an analysis of its supporting elements. The world economic forum puts forward eight pillars of entrepreneurship ecosystem, namely, market openness, human capital, financing and financing, tutor consulting and supporting system, rules and regulations and facilities, education and training, University catalysis and culture. The first three are considered to be the leading factors in the formation of the entrepreneurial ecosystem. Global Entrepreneurship observation suggests that the framework of entrepreneurial ecosystem includes nine aspects: financing channels, government policies, government entrepreneurship planning, entrepreneurship education, R \& D transfer, business and law basis, market openness, physical infrastructure and cultural and social norms. On the whole, the core elements of entrepreneurship ecosystem are enterprises, policies, finance, education, law, resources, and entrepreneurial environment, and other factors that form an ecological network around the development, survival and development of enterprises. Among them, the development of education or human capital is an essential ecological factor for the entrepreneurial ecosystem. The ecological system of entrepreneurship education is an important branch of the entrepreneurial ecosystem, but it also constitutes a unique internal ecological system. At present, the research on the ecological system of entrepreneurship education is still in its infancy. The world economic forum has proposed that entrepreneurship education in Colleges and universities is an ecological system, with individual and intermediate human center. Entrepreneurial academic institutions, business enterprises and governments support the center [1]. Among them, the government gave support and support to the social 
forces such as business enterprises and established social partnership as an extension of pre-school, secondary, higher education and informal education institutions.

\section{THE ROLE AND SIGNIFICANCE OF PROMOTING THE} TEACHING WORK AND IMPROVING THE QUALITY OF TEACHING.

\section{A. Developing a more entrepreneurial spirit and entrepreneurial potential}

entrepreneurship education is a real entrepreneurial talent training, graduate students with work experience based professional knowledge, the appropriate and necessary the economic foundation, in an entrepreneurship education can quickly become entrepreneurial practice, entrepreneurial talent. How to carry out entrepreneurship education in education, launch entrepreneurial project and cultivate compound entrepreneurial talents to meet the needs of regional economic development is an important issue faced by educators in Colleges and universities, which has far-reaching practical significance. The ecological system of entrepreneurship education is a systematic project. According to the target level of the system operation, the talent training is the highest level, and the innovation and entrepreneurial talent is the core of the ecological system of entrepreneurship education. Student groups and teacher groups constitute schools. Communities, such as schools, families, governments, enterprises and other social organizations, occupy the corresponding niche. Among them, the school system is the core of the ecosystem. Government, family, enterprises and other social organizations as input (IE) environment generate energy input to schools, and innovative and entrepreneurial talents are exported to the society as human capital.

Based on the entrepreneurial ecosystem of universities, strong university support, continuous financial resources and appropriate organizational mode are important factors to guarantee the entrepreneurship education ecosystem in universities. It is often with the level of individual level, including: students, teachers, practitioners and managers, group level and organizational level, event level, level of stakeholders. Among them, the internal ecosystem is the core of entrepreneurship education based on University Entrepreneurship ecosystem, including entrepreneurship courses, entrepreneurship, entrepreneurship research three overlapping and support areas, and rely on culture, resources, stakeholders, facilities, schools and local communities to support external factors. Entrepreneurship Education in western developed countries has trained a large number of entrepreneurs and promoted the economic development. Developing countries should learn from the experience of entrepreneurship education in developed countries.

\section{B. Deepening the concept of entrepreneurship education}

The research of entrepreneurship education curriculum construction is conducive to deepening the concept of entrepreneurship education in universities, making clear the objectives of entrepreneurship education curriculum, and promoting the development and improvement of entrepreneurship education curriculum theory in China. Finally, the research on the construction of entrepreneurship education curriculum is conducive to enrich the curriculum, strengthen the construction of entrepreneurship education, entrepreneurship education teachers in China to improve the teaching conditions, entrepreneurship education curriculum for university administrators in entrepreneurship education management to provide some suggestions and references.

\section{MAIN PROBLEMS OF ENTREPRENEURSHIP EDUCATION}

\section{A. Value deviation of entrepreneurship education}

Entrepreneurship education is a systematic project, which not only needs a systematic and perfect system of entrepreneurship education, but also needs to improve the importance and understanding of entrepreneurship education. At present, the expectation of the parents, the idea of the graduates, the public opinion of the society, the guidance of the government and the focus of the colleges and universities are focused on improving the employment rate of the students. However, parents generally stay in "looking for a stable and secure unit is the right way"; graduates are still immersed in the "job seekers" role, not aware of their own may also become job creators; the government neglected in the entrepreneurial motivation and entrepreneurial policy guide, service, support, entrepreneurial environment and entrepreneurial education services etc. in terms of social responsibility; entrepreneurship education in Colleges and universities is only limited to the basic education, entrepreneurial guidance on the cultivation of students' awareness of entrepreneurship and entrepreneurial spirit, entrepreneurial knowledge and entrepreneurial ability no systematic arrangement, a general lack of understanding of the value of entrepreneurship education, entrepreneurship curriculum does not reflect the importance of entrepreneurship education in the employment category the neglect of the fundamental role of entrepreneurship education [2].

\section{B. Entrepreneurship education is not integrated with professional education}

In fact, the implementation of entrepreneurship education in China's colleges and universities has not really included in the school curriculum system. Set from the training framework of the whole system of entrepreneurship education curriculum in Colleges and universities, and the lack of integration with other courses, nature, entrepreneurship courses, teaching content and teaching methods have not been clear, which directly affects and restricts the students with their studies, will be directly applied to the entrepreneurship of entrepreneurial skills process. Job category most universities entrepreneurship education will be simply put into the school enrollment and employment department or departments, the operation form is equivalent to the students before graduation training, the construction of entrepreneurship has been excluded; there are some universities to stay in and engage in some entrepreneurial activities, mode of closure, the contents of the old, through simple lectures, organized entrepreneurship contest and other forms to implement entrepreneurship education. Some colleges and universities are relatively active, and vigorously set up all kinds of "pioneer parks", so as to create convenient incubators for students, help students 
improve their entrepreneurial capabilities and solve their employment problems. In fact, entrepreneurial ability is not innate [3]. It is far from enough to provide only entrepreneurial establishments. We must rely on a specialized entrepreneurship education discipline system to enable students to improve their entrepreneurial ability through educational practice based on understanding entrepreneurial ideas and entrepreneurial knowledge.

\section{No effective mode of entrepreneurship education has been established}

Entrepreneurship education has not formed a systematic and standardized operation system, operation mechanism of College Students' Entrepreneurship involved in all aspects of the obvious lack of systematic, standardized, macro policy, a business service lead system is obviously insufficient there, policy gaps, policy conflict, policy, policy deficiencies such as fuzzy misreading. Especially the entrepreneurial operation mechanism of three linkage of universities, government and enterprises is not implemented, the empirical research on entrepreneurship education and regional economic development how to practice the problem of lack, lack of entrepreneurship education in Colleges and universities to promote the regional economic development policy design, resulting in the entrepreneurial reality, lack of government and business support, operation poor, low success rate [4]. Teachers in entrepreneurship education cannot follow the development needs, entrepreneurship education involves opportunity identification, financing, team building, project selection and management and many other interdisciplinary content, is the most comprehensive and challenging subject, but also a very strong practical science. This kind of course requires teachers to use personal experience to guide students to participate in the process of practice, emphasizing the importance of knowledge and practice. The teacher's knowledge, experience and experience determine the effect of classroom teaching to a great extent.

\section{THE CONSTRUCTION OF THE ENTREPRENEURSHIP ECOLOGICAL EDUCATION}

\section{A. Setting rational the goal system of entrepreneurship education}

The construction of entrepreneurship education ecosystem development system is a deepening and transformation of a talent training mode that universities actively comply with the development of the times. It is also the concrete implementation of implementing the concept of quality education and innovative talents training. That is to say, the ecological development system of entrepreneurship education in Colleges and universities is the same as talent training, and the real quality is to solve the problem of "what kind of talents to cultivate". The development of entrepreneurship education in Colleges and universities is not only to cultivate the ability of the students to start the business, but also not to make all the students start a business. It is the ultimate goal of entrepreneurship education to train innovative talents and enhance college students' social adaptability, so that more college students have the ability of independent development and risk fighting in the future career development. Entrepreneurship Education in Colleges and universities is a high level of quality education, all-round development of education and sound personality education [5]. The goal of the ecological development system of entrepreneurship education in Colleges and universities is closely related to the goal of the overall training of talents in Colleges and universities. On the one hand, the teaching of entrepreneurship in Colleges and Universities. The concept of ecological development is a new educational concept and educational content or educational way under the guidance of this concept. It focuses on the cultivation of contemporary college students' entrepreneurial consciousness, entrepreneurial spirit and entrepreneurial ability. And personnel training is the central task of colleges and universities. It is made up of multiple contents and ways. In order to complete the task of personnel training, we must design various educational contents and educational methods according to the goal of talent cultivation. In this sense, the ecosystem development system of entrepreneurship education in Colleges and universities is only part of the personnel training system in Colleges and universities, and it must integrate or serve the overall situation of talent training in Colleges and universities [6]. On the other hand, the construction of ecological development system of entrepreneurship education in Colleges and universities is based on the cultivation of entrepreneurial quality. It is based on quality education to deepen and reform talents training in universities, and it is also a basic support for talents training. The training of talents is the ecological development system of entrepreneurship education in Colleges and universities.

\section{B. Integrating entrepreneurship education and professional curriculum}

Many colleges and universities set up entrepreneurship courses in an independent running state, and did not incorporate into the whole curriculum system of the school. They failed to integrate with other courses and lacked interaction with other disciplines. Entrepreneurship curriculum is too much emphasis on classroom theory teaching, while ignoring the characteristics of perception and perception in the practice and operation process, students feel little practical utility. Therefore, the curriculum system of ecological development of entrepreneurship education in Colleges and universities needs to be brought into the training of the whole university [7].

\section{Building up a good teacher team for entrepreneurship education}

To build up a teacher system for the ecological development of entrepreneurship education in Colleges and universities, we should first strengthen the construction of the teaching staff of the ecological development of entrepreneurship education in Colleges and universities. First, the advantages of the internal resources of the school and the teachers outside the school should be complemented. Colleges and universities can combine their own school running characteristics and entrepreneurship education orientation, invite well-known experts or entrepreneurs to train teachers regularly, let them know the latest development of the industry, enrich related theories, and improve teaching means and 
teaching contents [8]. Two the teaching team should be set up effectively. Cross, cross major professional teaching and entrepreneurship teaching teachers, theory teaching and school enterprise cooperation can be a part-time tutor, the teaching team to complete the teaching goal, not only can play their respective expertise and strengths, also can broaden the members through the internal team communication perspective, deepening understanding of exchange theory and practical experience, improve the teaching level. Three the emphasis should be given to strengthening the training of teaching methods for teachers. The teaching method of ecological development course of College entrepreneurship education emphasizes the application of situational teaching and interactive teaching more than other courses. In addition to instilling common teaching methods, teaching method to use heuristic and interactive, case study, role playing, complemented by group discussions, and other forms of business simulation, the outstanding realistic examples analysis and practice activities carried out in the whole process of teaching, to make students in the context of business simulation.

\section{CONCLUSION}

The construction and development of university entrepreneurship education ecological system should focus on the fostering of students' comprehensive quality of this goal, construct the corresponding curriculum system and teaching content, knowledge structure, improve the comprehensive quality of the students needed to start a business, let the student have found new value thinking, keen understanding of creating new value of essential knowledge and skills, mastery of creating new value the law. At the same time, we should seriously study the characteristics and rules of entrepreneurship education, reform teaching methods, strengthening practice, explore new ways of education, the implementation of entrepreneurship education as the main channel of entrepreneurship training, entrepreneurship education as the main position to improve personnel training quality, pay attention to the combination of entrepreneurship education and quality education, to ensure that the content of entrepreneurship education is more forward-looking and strategic.

\section{ACKNOWLEDGEMENT}

This research was financially supported by Wuhan University of Science and Technology.

2017 graduate education and teaching reform research project "MBA entrepreneurship education research based on entrepreneurial ecosystem" NO.Yjg201723.

This research was financially supported by The project of innovative and entrepreneurial training program for provincial university students in Hubei in 2017: Study on the influence on their employment and Entrepreneurship of the college students' participation in the zero work economy, NO: 201710488037

\section{REFERENCES}

[1] Cai Li, Peng Xiuqing, Satish Nambisan, et al. Review And Prospect Of Research On Entrepreneurial Ecosystem [J]. Journal of Social Sciences of Jilin University, 2016 (1): 5-16. (In Chinese)

[2] Dong Yini, Xu Yang. Construction Of The Ecological Development System Of Entrepreneurship Education In Colleges And Universities [J]. Chinese College Students' Employment, 2013 (2): 42-46. (In Chinese)

[3] Yan Mao Xin. From The Perspective Of Social Entrepreneurship Ecological System, The Development Of Entrepreneurship Education In Colleges And Universities [J]. Education Research, 2015 (5): 48-55. (In Chinese)

[4] Chen Wenhua, Qiu Guiming. College Students' Entrepreneurship Education In Social Ecosystem [J]. Jiangsu High Education, 2007 (5): 85-87. (In Chinese)

[5] He Yubing, Ding Jiamin, et al. How To Build An Entrepreneurial Education Ecosystem In An Entrepreneurial University? [J]. Science Research, 2015, 33 (7): 1043-1051. (In Chinese)

[6] Ma Yongbin, Bai Zhe. The Construction Way Of Innovation And Entrepreneurship Education Curriculum Ecosystem -- Analysis Of Tsinghua University Entrepreneurship Education Based On The Case Study Of Higher Education Of Engineering [J]., 2016 (5): 137-140. (In Chinese)

[7] Zhu Jian. Entrepreneurship Education In Colleges And Universities Should Focus On Building An Entrepreneurial Ecological System [J]. Chinese Higher Education, 2015 (17): 14-17. (In Chinese)

[8] Huang Guohui. Construction Of The Ecological System Of Entrepreneurship Education For College Students In Local Colleges And Universities [J]. Innovation And Entrepreneurship Education, 2015 (1): 21-24. (In Chinese). 